\title{
Pragmatic Language Abilities of 9-Year-Old Children on a Nation-Wide Survey: Effects of Gender and Socioeconomic Status
}

\author{
So Jung Oh \\ Department of Communication Disorders, Tongmyong University, Busan, Korea
}

Correspondence: So Jung $\mathrm{Oh}, \mathrm{PhD}$ Department of Communication Disorders, Tongmyong University, 428 Sinseon-ro, Nam-gu, Busan 48520, Korea

Tel: $+82-51-629-2132$

Fax: +82-51-629-2019

E-mail: sjoh@tu.ac.kr

Received: April 22, 2019

Revised: May 16, 2019

Accepted: May 16, 2019
Objectives: Improvement of conversation and communication skills has often been regarded as a major feature of language development during school-age. The main purpose of this study was to describe the pragmatic language abilities of 9-year-old children. The current study also examined whether these abilities vary according to the child's gender and socioeconomic status (SES), and the effects of these factors on pragmatic language abilities. Methods: Performance data on the Children's Pragmatic Language Checklist (CPLC) and information regarding child and family characteristics were collected from 1386 children participating in the 'Panel Study on Korean Children (PSKC)' of the Korea Institute of Child Care and Education. Total and subtest scores of the CPLC were obtained for descriptive statistics and a one-way ANOVA and $t$-test were used to compare group differences, as well as a multiple regression analysis for seeking affecting factors for performance on the CPLC. Results: In general, 9-year-old children obtained good scores in CPLC total and subtest scores. Discourse management was relatively difficult when compared to the other sub-areas. The children's gender and SES (education level of mother, monthly family income) brought significant group differences, as well as the size of their residential areas. The educational level of the mother alone, along with the child's gender, affected the pragmatic abilities of 9-year-old children. Conclusion: The results of the current study showed that 9-year-old children have fair pragmatic, communication skills, and suggested that child gender and SES should be considered in assessment and intervention of pragmatic language abilities.

Keywords: Gender, SES, CPLC (Children's Pragmatic Language Checklist), School-aged children, PSKC (Panel Study on Korean Children)
학령 전기의 언어발달이 발화 길이의 증가 등 언어의 형식면의 변화가 두드러지는 특징을 보인다면 학령기 언어발달은 또래와 대 화하는 시간이 증가하여 다른 사람의 관점에서 생각하기가 가능해 지면서 상대방을 고려하는 대화기술의 발달이나 설득이나 협상 등 의 고급한 의사소통 기능의 사용 등 화용면의 발달이 두드러진다. 최근 DSM-5에 사회적(화용적) 의사소통 장애(social pragmatic communication disorders)가 아동언어장애 영역의 새로운 진단명 으로 등장하는 등 국내외에서 아동의 화용언어능력에 관심이 많아 지고 있다.
담화관리 능력은 대화차례를 이어나가고 주제를 적절히 개시, 유 지, 변경하는 비율인데, 학령기 아동은 점차 한 주제로 대화를 길게 이어나갈 수 있게 되며, 상대방의 말에 적절한 언급을 하는 비율이 늘어나며, 주제를 매끄럽게 전환할 수 있게 된다(Nippold, 2007). 연령별 비교 연구에서는 학령전기 아동보다는 학령기 아동이, 또 학령기 저학년 아동보다는 고학년 아동이 대화 주제를 유지하면서 차례를 길게 주고 받을 수 있는 것으로 보고되었다(Brinton \& Fujiki, 1984; Brinton, Fujiki, \& Powell, 1997; Sehley \& Snow, 1992). 국 내 $1,3,5$ 학년 아동을 대상으로 대화 화제관리 능력의 발달을 살펴 
본 Park, Choi와 Lee (2017)에서도 학년 증가에 따라 전체 화제수는 줄어들고, 한 주제당 대화차례수는 늘어나며, 화제유지 비율은 늘 어나고 화제변경 비율은 감소하였다. 학령기 중반에 해당하는 3-4 학년 아동의 경우 아직까지 고학년 아동에 비하여서는 주제당 대 화차례수나 전체 화제수가 많고 화제변경 비율도 높은 반면 화제유 지 비율은 낮은 것으로 보고하였다.

학령기 의사소통 기능을 연구한 선행연구에 따르면 학령기 저학 년 시기에는 인지적인 변화에 영향을 받아 앞일을 계획하고 모니터 링하는 지시적 기능, 연관짓기나 순서와 이유 인식하기와 같은 해석 적 기능, 사건/결과/대안을 예측하는 등의 투사적 기능, 자기를 정 당화하고 남을 비판하거나 자기 욕구를 표현하는 관계적 기능 등 고급한 의사소통 기능들이 사용된다(Tough, 1977). 또, 학령전기 의 후기에서 학령기에 접어들면서 제 3 의 사람이나 사물에 대하여 정보를 제공하는 참조적 의사소통이 발달하기 시작하며(Davies, Andrés-Roqueta, \& Norbury, 2016), 학령기 초기 아동도 간접적인 행동 요구하기가 가능하였고, 부적절한 요구에 대한 판단하기와 같 은 메타화용능력을 보여주었다(Wilkinson, Wilkinson, Spinelli, \& Chiang, 1984). 국내연구에서 일반적인 언어발달을 보이는 학령기 아동은 3-4학년인 중학년 시기에 간접적인 요구를 이해하고 표현 할 수 있게 되고(Kim, Song, Kim, \& Kim, 2018), 구어 담화를 이해 하는 능력이 저학년에 비해 발달하며(Lee, Heo, \& Jang, 2015), 대화 차례를 개시하기와 반응하기 모두에서 친사회적이고 덜 독단적, 이 탈적, 소극적인 특성을 보이는 것으로 나타났다(Jin \& Pae, 2014). 아동이 10 세가 되면 문제 해결을 위해 또래와 협상하고 논쟁을 할 때 상대방의 관점을 이해함을 표시할 수 있게 된다(Nippold, 2007).

말은 어느 상황에서 누구에게 하느냐에 따라 적절성이 달라질 수 있으므로 상황에 맞게 말의 내용이나 형식 등을 조정하는가도 중요한 화용언어능력이다. 학령기 아동은 듣는 사람에 맞춰 자기 말의 내용이나 형식을 조정할 수 있으며, 상대방의 나이나 지위에 맞게 예의를 갖춰 말할 수 있게 된다(Nippold, 2007; Philofsky, Fidler, \& Hepburn, 2007). 학령기 아동의 상황과 상대방에 따른 조 절 능력을 살펴본 Kim, Song 등(2018)에 따르면 한국아동 메타-화 용언어검사(KOPLAC)에서 학령기 아동의 대화 상대방에 따른 조 절 능력과 상황문맥에 따른 조절능력 점수는 학년이 높아짐에 따 라 유의하게 증가하였으며 특히 3학년 아동은 두 영역 점수에서 모 두 저학년 아동에 비해 유의하게 높은 수행을 보였고, 고학년 아동 과도 유의미한 수행 차이를 보이지 않아서 초등학교 중학년 시기에 이미 이러한 의사소통 조절 능력이 상당히 발달되어 있음을 보고 하였다. 또한 앞뒤 맥락에 맞게 결속 장치를 사용하는 빈도가 늘어
나며 정확도도 높아지게 된다(Ripich \& Griffith, 1988).

이렇듯 일반적으로 학령기 동안 아동의 의사소통 능력은 비약적 으로 발달하지만 언어발달의 모든 영역과 시점에서 개인차에 따른 다양성은 존재하며, 이러한 개인차는 어휘 및 문법, 문해기술뿐 아 니라 아동의 의사소통 능력에서도 나타난다. 전통적으로 언어발달 에서의 개인차를 가져오는 요인으로 언급된 것이 부모의 사회경제 적지위(socio-economic status, SES)이다. 사회경제적지위는 초기 어휘발달에 주는 영향이 가장 많이 보고되었는데, 구어 발달의 시 작기인 16-18개월부터 어휘발달에 미치는 사회경제적지위의 효과 는 유의한 것으로 나타났으며(Arriaga, Fenson, Cronan, \& Pethick, 1998; Fernald, Marchman, \& Weisleder, 2013), 시간이 지나면서차 이가 점점 커져 교육을 많이 받은 부모의 자녀가 교육을 덜 받은 부 모의 자녀보다 더 많은 어휘를 갖고 있음이 보고되었다(Hart \& Risley, 1995, 1999; Hoff-Ginsberg, 1998). 언어경험이나 학습의 영 향을 덜 받는 것으로 여겨지는 비단어따라말하기(nonword repetition task)에서도 낮은 SES 집단은 중상위 SES 집단에 비해 유의하 게 낮은 수행을 보였다(Chiat \& Polišenská, 2016). 물론 빈곤한 가 정 아동의 언어능력 수준은 매우 다양하며 일부 아동은 양호한 언 어능력을 보이기 때문에 이들의 언어문제를 일반화하는 것에 대한 주의할 필요성이 있다. 하지만 SES 자체보다도 낮은 SES를 가진 계 층 부모들이 SES가 높은 부모들에 비해 더 적은 어휘, 덜 복잡한 구 문구조와 다양하지 못한 통사구조를 사용하며(Hoff, 2003; Huttenlocher, Vasilyeva, Waterfall, Vevea, \& Hedges, 2007), 이러한 어 머니의 가정 내 언어사용이 아동의 구어 기술에 영향을 주고 다시 이 구어 기술이 이후 읽기나 학업성취에 영향을 주어 결과적으로 SES가 구어 기술을 매개로 이후 문해능력(Hoff, 2003, 2006), 음운 인식능력(McDowell, Lonigan, \& Goldstein, 2007)이나 학업성취 (Bowey, 1995; Burchinal, Peisner-Feinsberg, Pianta, \& Howes, 2002; Hammer et al., 2017; Walker, Greenwood, Hart, \& Carta, 1994)에도 영향을 주고 있음이 보고되었다. SES가 언어발달에 영 향을 주는 근거로 빈곤층의 건강유지의 어려움과 양육자의 낮은 학력 수준과 높은 스트레스 수준 등이 학습적 경험에의 노출 부족 으로 이어지기 때문으로 설명하기도 하였다(Roseberry-McKibbin, 2007).

최근 대규모 자료를 이용한 언어장애의 종단적 연구에서도 어머 니 학력이 높을수록 높은 어휘 수준을 보였으며, 가난한 아동 집단 에서 단순언어장애나 말언어 문제가 나타날 확률이 그렇지 않은 아동 집단에 비해 높았고(Raghavan et al., 2018), 부모의 낮은 SES 가 말늦은아동(late-talker) 발생과 높은 상관이 있었다(Fisher, 2017). 
국내에서는 전반적으로 저소득층 아동의 언어에 대한 연구가 부 족한 편인데, 저소득층 밀집지역 만 4,5 세 아동 대상 연구결과, 소 득수준에 따른 언어능력 차이가 유의하여 전반적인 언어와 어휘력 및 단어 읽기에서 일반 중산층 가정, 차등 보육료지원대상 가정, 법 정 저소득 가정 유아 순으로, 소득수준이 낮아질수록 언어수준이 낮은 것으로 나타났다(Han, 2011). 차상위계층 아동이나 사회취약 계층 아동들이 주로 이용하는 지역아동센터 아동들의 언어수준 에 대한 설문연구에서도 약 $10 \%-30 \%$ 의 아동이 어휘력이나 메시지 전달력, 책 내용 이해나 줄거리 이야기하기, 작문 등의 언어학습능 력에 문제를 보인다고 보고되었다(Lee \& Park, 2015). 국내 연구에 서도 저소득층 가정 아동의 초기의 언어발달 지연은 학령기에 읽 기 능력의 저하로까지 이어져 저소득층 학령기 아동은 중상위층 가정 아동보다 낱말해독과 읽기유창성에서 유의미하게 낮은 수행 력을 보였다(Kim, Pae, \& Yoon, 2013). 친숙도와 투명도에 따른 관 용어 이해능력 또한 학년이 올라갈수록 차이가 줄어들긴 했지만 소득이 낮은 가정 출신 아동이 중산층 가정 아동에 비해 낮은 수행 을 보여, 이들을 대상으로 저학년에서의 관용어 및 의미 중재가 필 요함을 시사하였다(Kim \& Jung, 2017).

의미나 문법 등 다른 언어영역 발달보다는 적었지만 의사소통능 력 발달에도 SES의 영향이 언급되었다. SES가 낮은 아동들은 그렇 지 않은 아동 집단에 비해 의사소통 기능 발달(Tough, 1982)이나 내러티브와 주제 응집력에서도 세련되지 못한 것으로 보고되었으 나(Heath, 1983), 국내에서는 SES에 따른 아동의 화용언어능력 차 이에 대한 연구가 거의 없었다.

해외의 언어장애 출현율이나 언어치료가 의뢰된 사례를 분석한 연구에서는 SES와 함께 성별의 영향이 보고되는 경우가 많았다 (Broomfield \& Dodd, 2004; Law, McBean, \& Rush, 2011). 특히, 언 어장애 출현율 연구에서 성별의 차이는 여러 가지 의사소통 장애 에서 지속적으로 보고되어 왔다. 국내에서도 언어발달 초기인 영아 기에서부터 성별에 따른 차이가 보고된 바 있으며(Yoon \& Kim, 2004), 최근에는 대규모 연구에서 말소리 오류율(Kim, Ko, Seo, \& $\mathrm{Oh}, 2017)$ 이나 어휘량(Kim, Kim, \& Do, 2018)에서 여자 아동이 남 자 아동에 비해 우수한 수행을 보임이 보고되었다. 최근의 성별차 이 연구에서 장기간의 어휘 발달에 대한 종단적 연구결과, 2 세부터 학령기 초기에는 여자 아동이 어휘발달에서 더 유리한 모습을 보 였으나 10-21세에서는 이런 경향성이 역전되어 남자 아동의 어휘 수준이 더 높았다고 보고되기도 하였다(Rice \& Hoffman, 2015). 성별의 차이는 어휘나 음운뿐 아니라 화용면에서도 보고되었는데, 화용언어능력을 체크리스트로 평가하는 Children's Communication Checklist (CCC; Bishop, 1998)로 살펴본 대규모 연구에서 남
자 아동은 여자 아동에 비교했을 때 2.6:1.0의 높은 비율로 화용언 어장애를 보이는 것으로 보고되었다(Ketelaars, Cuperus, van Daal, Jansonius, \& Verhoeven, 2009). 8세 여자 아동은 대화차례 중첩 하위영역과 동시성 해결 패턴에서 차이를 보였고, 대화에서 남자 아동은 주장하기를 여자 아동보다 자주 사용하는 것으로 보 고되었다(Craig \& Evans, 1991). 동의어를 인식하는 메타언어적 인 식 과제에서도 9-12세 아동 집단에서 성별 간 유의한 차이가 나타 났다(Corthals, 2010). 또 여자 아동은 좀 더 공손한 표현을 쓰는 등 (Gleason \& Ely, 2002) 화용면에서도 성별에 따른 차이가 다양하게 보고되었다.

거주지의 규모나 지역이 언어발달에 영향을 주는가에 대해 해외 에서는 주로 SES와 관련지어, 낮은 SES를 보이는 비주류지역(도시 빈민가 지역이나 시골)과 높은 SES를 보이는 지역 간 언어수행이나 사투리(dialect) 사용을 비교하는 연구가 주로 이루어져 왔다(Oetting \& McDonald, 2001). 이러한 연구들은 해외에서는 인종 및 SES 에 따른 거주지 분포가 우리와는 다르고, 방언의 차이가 언어평가 에 주요 이슈가 되지 못한다는 점에서 우리나라 실정과는 다소 맞 지 않는 면이 있다. 국내에서는 다문화가정 아동을 도시지역과 농 촌지역 거주 아동으로 나누어 살펴보거나 이들의 어머니 출신지가 시골인지 대도시인지에 따라 집단을 나누어 언어수행을 비교하는 연구(Hwang, 2007) 외에 거주지 규모에 따른 연구가 드문 편이다.

위에서 살펴본 바와 같이 해외 문헌에 비해 국내에서는 SES (부 모의 학력이나 소득)나 아동의 성별, 거주지 규모에 따라 언어발달 에 차이가 있는지 비교한 연구가 드물며, 대규모 샘플을 이용한 체 계적 비교연구는 더더욱 찾아보기 어렵다. 특히 초기 언어발달 시 기인 학령 전기의 어휘, 학령기 문해력 등에 한정되어 소득 등 한 가 지 요인만을, 상대적으로 적은 인원수로 연구하고 있고, 대규모 자 료를 체계적으로 분석한 연구나 화용언어나 의사소통과 관련한 연 구가 거의 없다.

한국아동패널연구는 한국육아정책연구소에서 전국에서 2008 년 4-7월에 태어난 아동을 인구사회학적 균형을 이루도록 수집하 여, 매해 종단적으로 아동의 발달 특성, 가정 환경 특성, 부모의 양 육 특성, 교육기관 경험 특성, 보육 및 교육정책 서비스 특성, 지역사 회 특성 등 육아와 교육과 관련된 다양한 정보를 수집하고 있는 대 규모 연구이다. 언어발달과 관련한 자료로는 학령전기였던 2014년 까지 주로 수용·표현어휘력검사를 통해 어휘능력 자료를 수집하였 으며, 학령전기 후기였던 7차 연구(2014년)에서는 아동의 말소리 발달 자료를 특별히 추가해 심층 조사하였다. 이 자료를 이용한 연 구로 아동의 어휘 발달이 3-7세까지 종단적으로 SES와 성별, 출생 순위 등에 영향을 받음이 보고되었고(Kim, Kim, et al., 2018), 6세 
아동의 말소리 장애 출현율이 보고되었으며 말소리 출현율에 있어 서 성별에 따른 유의한 차이가 있음도 확인하였다(Kim et al., 2017). 패널연구 참여 아동이 2017년에 9세로 학령기 중반에 접어 듦에 따라 어휘력보다는 또래 관계 및 학교 적응 등에 영향을 줄수 있는 의사소통 능력에 대한 자료 수집이 요구되어, 2017년부터 아 동화용언어체크리스트(Children's Pragmatic Language Checklist, CPLC; Oh, Lee, \& Kim, 2012)를 이용하여 의사소통 능력에 대한 자료를 수집하고 있다(Do et al., 2019).

따라서 본 연구에서는 선행연구에서 다양한 화용언어능력의 변 화가 나타난다고 보고되는 학령기 전반기, 9세 아동을 대상으로, 지역과 사회경제적지위 등의 인구학적 요인이 고려된 전국적 설문 조사에 나타난 화용언어능력을 전반적, 영역별로 살펴보고자 한 다. 또한, 전통적으로 아동의 언어발달에 영향을 주는 요인으로 언 급되어 온 아동의 성별이나 부모의 사회경제적지위, 거주지의 규모 등에 따라 아동의 화용언어능력에 차이가 있는지 알아보고자 한 다. 마지막으로 여러 관련 변인들 중 아동의 화용언어능력에 유의 미한 영향을 주는 요인을 찾아볼 것이다.

\section{연구방법}

\section{연구대상}

본 연구의 대상은 한국육아정책연구소의 2017년도 제 10 차 한국 아동 성장발달 종단연구(한국아동패널)에 참여한 9 세 아동 중 자 폐범주성장애, 지적장애, 의사소통장애, 정서 및 행동장애 등 장애 아동의 자료를 제외한 1,386 명의 아동이었다. 한국육아정책연구소 의 한국아동패널연구는 전국적으로 2008년 4-7월 의료기관 출생 아 중 소득과 거주지역을 인구학적 비율에 맞추어 선발한 표본집 단을 대상으로 성인기에 진입하는 2027년까지 매년 종단적으로 전 반적인 아동 발달 특성과 부모 특성, 가정 환경 특성, 교육(학교 및 사교육) 특성, 지역사회 특성, 정책 특성 자료를 수집하는 대규모 조사연구 프로젝트이다.

대상 아동들은 초등학교 3학년에 재학 중이었으며 이들의 평균 연령은 9.44세, 월령은 평균 112.63 개월( $\mathrm{SD}=1.43)$ 이었으며, 성별은 여아가 $49.42 \%$ (685명), 남아가 $50.58 \%$ (701명)이었다. 어머니 취업 여부에 따라서는 취업한 어머니를 둔 아동이 $51.44 \%$ (713명), 전업 주부 어머니를 둔 아동이 $46.68 \%$ (647명)이었고, 어머니 최종학력 은 고졸 이하가 $0.4 \%$ (5명), 전문대졸이 $55.41 \%$ (768명), 대졸 이상 이 $43.80 \%$ (607명)이었고 가정의 소득수준별로는 340 만 원 이하인 가정 아동이 $16.88 \%$ (234명), 341-400만 원인 가정 아동이 $18.54 \%$ (257명), 401-530만 원까지인 가정 아동은 $24.46 \%$ (339명), 531만 원
Table 1. Participants' information $(\mathrm{N}=1,385)$

\begin{tabular}{lc}
\hline Characteristic & No. (\%) \\
\hline Gender of children & $685(49.42)$ \\
Female & $701(50.58)$ \\
Male & \\
Employment of mother & $713(51.44)$ \\
Employed & $647(46.68)$ \\
Unemployed & $26(1.87)$ \\
No response & \\
Education level of mother & $5(0.4)$ \\
$\leq$ High school & $768(55.41)$ \\
College & $607(43.80)$ \\
$\geq$ University & $6(0.4)$ \\
No response & \\
Monthly income (thousand KRW) & $234(16.88)$ \\
$\leq 3,400$ & $257(18.54)$ \\
$3,400-4,000$ & $339(24.46)$ \\
$4,010-5,300$ & $421(30.38)$ \\
$\geq 5,310$ & $135(9.7)$ \\
No response & \\
Residence size & $546(39.39)$ \\
Metropolis & $76(5.48)$ \\
Rural & $764(55.12)$ \\
Mid-city & \\
\hline
\end{tabular}

KRW= Korean won.

이상인 아동이 $30.38 \%$ (421명)이었다. 거주지 규모별로는 대도시 거주 아동이 $39.39 \%$ (546명), 읍/면 단위 지역 아동이 $5.48 \%$ (76명), 중소도시 지역 아동이 $55.12 \%$ (764명)이었다. 자세한 대상자 구성 정보는 Table 1 에 제시하였다.

\section{도구}

아동의 화용언어능력에 대한 자료수집은 표준화 과정에 있는 아 동화용언어체크리스트(CPLC)의 문항을 수정을 거쳐 사용하였다. $\mathrm{CPLC}$ 는 아동의 대화 기술 및 의사소통 능력을 양육자 설문을 통 하여 검사하는 체크리스트로 전체 44 문항으로 구성되어 있으며, 각 문항에 전혀 그렇지 않다 0 점-매우 그러하다 3점까지 4점-Likert 척도로 응답하도록 되어 있다. 하위 영역은 아동이 대화 시 주제 개 시/유지/변경이나 차례 주고받기와 관련된 담화관리 영역과, 상대 방이나 상황에 맞게 말 내용이나 말투 등을 조정하는 능력인 상황 에 따른 조절 영역, 다양한 의사소통 기능의 표현과 관련된 의사소 통 기능 영역, 대화 시 상대방과의 거리, 눈맞춤, 표정 등과 같은 비 언어적 의사소통 영역의 총 4 개의 하위 영역으로 구성되어 있다. $\mathrm{CPLC}$ 는 아동 대화 관찰을 통해 수집된 자료와 상관이 있는 것으 로 보고되었으며(Oh, 2018a), 예비표준화를 거쳐 검사자 간 신뢰도, 
Table 2. CPLC sub-area and examples of items

\begin{tabular}{llc}
\hline CPLC sub-areas & \multicolumn{1}{c}{ Examples of items } & No. of items \\
\hline Discourse management & $\begin{array}{c}\text { Topic management (topic initiation/ } \\
\text { maintenance/change) } \\
\text { Turn-taking in conversation }\end{array}$ & 10 \\
Contextual variation & $\begin{array}{l}\text { Adjustment for situation and listener } \\
\text { (reference skills and register) }\end{array}$ & 13 \\
Adequacy and variability of commu- \\
Nonmunication intent & $\begin{array}{l}\text { nicational function intent } \\
\text { Cognitive communication function } \\
\text { Indirect intent expression }\end{array}$ & \\
\hline & $\begin{array}{l}\text { Appropriate eye contact, distance, } \\
\text { facial expression } \\
\text { Understand and express gestures }\end{array}$ & 7 \\
\hline
\end{tabular}

$\mathrm{CPLC}=$ Children's Pragmatic Language Checklist.

문항내적 일치도, 공인타당도가 높은 수준인 것으로 보고되었으며 화용문제가 있는 아동을 대상으로 민감도와 특이도가 비교적 양 호한 것으로 나타났다(Oh et al., 2012; Oh, 2018b). 자세한 CPLC의 하위 영역과 문항 예는 Table 2에 제시하였다.

육아정책연구소의 한국패널연구에 의사소통 능력 조사에 사용 한 체크리스트는 기존의 CPLC를 한국아동패널연구의 다른 조사 설문문항과의 일관성을 갖추기 위해 ‘보통이다’ 3 점 항목을 추가하 여 ‘전혀 그렇지 않다' 1 점, '매우 그러하다' 5 점까지의 5 점 척도로 수정하고, 문장 표현을 수정하여 사용하였다. 문항 수정은 응답자 의 이해도를 높이기 위하여 일부 어휘나 표현을 매끄럽게 수정한 문장이 7 개, 예를 추가한 문항이 3 개였으며 대부분 문어체 수정 등 의 문항 내용에 영향을 주지 않는 범위의 윤문이었다(예: '있음을 표시한다' $\rightarrow$ '있다는 것을 표현한다', '적절한 물리적 거리를 유지한 다' $\rightarrow$ '너무 가깝거나 멀지 않게 적절한 거리를 유지한다', '친구를 놀리거나 농담을 구사한다’ $\rightarrow$ 예를 들어 '별명을 부르기' 추가 등). 기타 아동 및 부모, 가정 환경 특성에 대한 설문지는 기존의 패널 연구에 사용하던 것을 그대로 사용하였다.

\section{연구절차}

제10차 한국아동패널연구(2017년도) 조사의 절차대로 양육자 를 대상으로 아동의 일과, 발달 특성, 가정 환경 및 아동 양육 실태, 학교 생활, 학습 등에 대한 설문지를 우편 발송하였다. 한국아동패 널연구에서는 조사원을 훈련시켜 가정 방문을 통해 참여 아동이 나 부모를 인터뷰나 대면 조사하고, 아동의 발달검사를 실시하며 부모나 아동이 컴퓨터화된 인터뷰를 할 수 있도록 보조하고 확인 하도록 하고 있다. 아동화용언어체크리스트(CPLC) 검사지도 우편 으로 조사대상 아동 어머니에게 전달하고 어머니(부재 시에는 아
버지)가 지필식으로 기입하도록 하였으며, 우편 발송 2-3주 후 패널 연구 조사원의 가정 방문 시에 작성을 확인하고 수거하였다.

\section{자료 분석 및 처리}

아동화용언어체크리스트(CPLC)는 '전혀 그렇지 않다'부터 '매 우 그렇다'까지의 5점 Likert 척도로 응답하여 각 문항당 1-5점을 얻을 수 있었다. 이를 합산하여 CPLC 총 평균을 구하였으며, 각 하 위 영역별 평균점수를 계산하였다.

집단 간 차이를 알아보기 위한 분산분석을 실시하기 위해 어머 니 학력은 '고졸 이하'를 '1', '전문대 졸업을 '2', ‘4년제 대학 졸업 이 상’을 ‘3’의 범주 변수로 변환하였고, 가정 소득수준에 대한 선택형 질문의 응답 보기대로 ' 340 만 원 이하’를 ' 1 ', '341-430만 원'을 '2', '431-530만 원'을 '3', ‘530만 원 이상'을 ‘'의 범주 변수로 바꾸어 코 딩하였다.

가정 소득과 어머니 학력, 성별 등이 아동의 화용언어능력에 미 치는 영향을 알아보기 위한 중다회귀분석을 실시하기 위하여 가정 소득은 월평균 수입에 대한 개방형 질문(가정 총소득은 월 몇 만 원 입니까?)에 대한 응답('월 OOO만 원')을 그대로 사용하였으며, 어 머니 학력은 연속변수로 변환하기 위하여 교육년수로 변환하여 '중 학교 졸업’은 '9', '고등학교 졸업’은 ' 12 ', '2-3년제 대학 졸업'은 중간 값인 ' 14.5 ', ‘년제 졸업'은 ' 16 ' '대학원 졸업'은 ' 18 '로 변환하였다. 아 동의 성별은 '남자 아동' 이 ' 1 ', '여자 아동'이 ' 2 '로 코딩되어 있는 것 을 남자아동 '0', 여자 아동 ' 1 '로 변환하여 회귀분석을 실시하였다.

\section{통계적 분석}

대상 아동의 전반적인 CPLC 총점과 영역별 점수의 기술통계를 구한 후 성별 및 어머니 재직 여부에 따른 차이는 두 독립표본 $t$-검 정, 가정 소득수준과 어머니 학력, 거주지 규모에 따른 집단 간 화 용능력 차이는 일원분산분석을 실시하여 분석하였고 Scheffe와 $\mathrm{LSD}$ 사후분석을 실시하였다. 아동의 화용언어능력에 영향을 주는 요인을 알아보기 위하여 CPLC 전체 및 영역별 평균을 종속변수로, 어머니의 학력과 가정의 소득수준, 성별을 독립변수로 중다회귀분 석을 실시하였다. 모든 통계적 분석은 SPSS version 19 (SPSS Inc., Chicago, IL, USA)를 이용하여 실시하였다.

\section{연구결과}

\section{아동 및 가정 요인에 따른 아동화용언어능력 \\ 아동화용언어능력의 기술통계 결과}

전체 아동의 $\mathrm{CPLC}$ 의 전체 평균은 $4.07(\mathrm{SD}=0.49)$ 로 나타났다 
(Table 3). 하위 영역별로 살펴보면 담화관리 영역 평균 $3.97(\mathrm{SD}=$ $0.52)$, 상황에 따른 조절 영역 평균 $4.10(\mathrm{SD}=0.51)$, 의사소통 의도 영역 평균 $4.07(\mathrm{SD}=0.51)$, 비언어적 의사소통 영역 평균 $4.14(\mathrm{SD}=$ 0.51)로 나타나 전반적으로 화용언어능력 수행이 양호하였으며, 비 언어적 의사소통에서 가장 높은 점수를 받고 담화관리에서 가장 낮은 수행을 보였다.

평균점수의 분포를 살펴보면 CPLC 총 평균의 경우 2점 초과-3 점 이하가 $1.7 \%, 3$ 점 초과-4점 이하가 $52.5 \%$, 4점 초과-5점 미만이 $45.7 \%$ 였다. 각 영역별로는 담화관리 영역이 2점 이하인 아동 비율 이 $0.2 \%, 2$ 점 초과-3점 이하가 $3.8 \%, 3$ 점 초과-4점 이하가 $60.4 \%, 4$ 점 초과-5점 미만이 $35.7 \%$ 였고 상황에 따른 조절 영역에서는 평균 1 점 초과-2점 이하인 아동 비율이 $0.1 \%, 2$ 점 초과-3점 이하인 아동 이 $2.0 \%, 3$ 점 초과-4점 이하인 아동이 $50.6 \%, 4$ 점 초과-5점 미만인
아동이 $47.4 \%$ 였다. 의사소통 의도(기능) 영역에서는 평균점수 2점 초과-3점 이하인 아동 비율이 $2.3 \%, 3$ 점 초과-4점 이하인 아동이 $54.1 \%, 4$ 점 초과-5점 이하인 아동이 $43.6 \%$ 였고 비언어적 의사소통 영역에서는 평균 2점 초과-3점 이하인 아동 비율이 $1.9 \%, 3$ 점 초과4 점 이하인 아동이 $52.0 \%, 4$ 점 초과-5점 이하가 $46.2 \%$ 였다.

\section{성별에 따른 아동화용언어능력}

남자 아동의 CPLC 평균이 4.01 인데 비해 여자 아동은 4.13으로 아동의 성별에 따른 전반적 화용언어 수행에 유의한 차이가 있었으 며 $(t=4.831, p<.001)$, 전체 평균과 모든 하위 영역 평균에서 여자 아동이 남자 아동에 비해 유의하게 높은 수행을 보였다. 성별 영역 별 $t$-검정 결과는 Table 3, Figure 1에 대한 설명에 제시하였다.

Table 3. Comparisons of CPLC mean among groups

\begin{tabular}{|c|c|c|c|c|c|}
\hline & CPLC total & Discourse management & Contextual variation & Communication Function & Nonverbal communication \\
\hline Total $(\mathrm{N}=1,386)$ & $4.07(0.49)$ & $3.97(0.52)$ & $4.10(0.51)$ & $4.07(0.51)$ & $4.14(0.51)$ \\
\hline \multicolumn{6}{|l|}{ Child gender } \\
\hline Male $(\mathrm{N}=701)$ & $4.01(0.49)$ & $3.90(0.53)$ & $4.03(0.52)$ & $4.01(0.52)$ & $4.09(0.50)$ \\
\hline Female $(\mathrm{N}=685)$ & $4.13(0.47)$ & $4.03(0.50)$ & $4.18(0.50)$ & $4.13(0.50)$ & $4.19(0.50)$ \\
\hline$t$ & $4.831^{* * *}$ & $4.598^{* * *}$ & $-5.384^{* * *}$ & $-4.354^{* * *}$ & $-3.595^{* * *}$ \\
\hline \multicolumn{6}{|l|}{ Mother employment } \\
\hline Employed ( $N=713$ ) & $4.08(0.49)$ & $3.98(0.53)$ & $4.11(0.52)$ & $4.09(0.51)$ & $4.16(0.51)$ \\
\hline Unemployed ( $\mathrm{N}=647)$ & $4.06(0.48)$ & $3.96(0.51)$ & $4.11(0.50)$ & $4.06(0.50)$ & $4.13(0.51)$ \\
\hline$t$ & .762 & 1.009 & .219 & .856 & .991 \\
\hline \multicolumn{6}{|l|}{ Mother education } \\
\hline$\leq$ High school $(\mathrm{N}=5)(\mathrm{A})$ & $3.48(0.85)$ & $3.46(0.99)$ & $3.43(0.87)$ & $3.46(0.80)$ & $3.66(0.76)$ \\
\hline College (N=768) (B) & $4.01(0.49)$ & $3.91(0.51)$ & $4.05(0.52)$ & $4.01(0.51)$ & $4.10(0.51)$ \\
\hline zUniversity (N=607) (C) & $4.15(0.47)$ & $4.04(0.51)$ & $4.19(0.49)$ & $4.15(0.50)$ & $4.20(0.49)$ \\
\hline$F$ & $16.411^{* * *}$ & $13.750^{* * *}$ & $16.807^{* * *}$ & $17.035^{* * *}$ & $9.342^{* * *}$ \\
\hline Scheffe post-hoc & $A<B<C$ & $A, B<C$ & $A<B<C$ & $\mathrm{~A}, \mathrm{~B}<\mathrm{C}$ & $B<C$ \\
\hline \multicolumn{6}{|c|}{ Family income (thousand KRW) } \\
\hline$\leq 3,400(\mathrm{~A})$ & $3.91(0.54)$ & $3.81(0.57)$ & $3.95(0.59)$ & $3.91(0.54)$ & $4.02(0.58)$ \\
\hline $3,400-4,000$ (B) & $4.00(0.42)$ & $3.89(0.44)$ & $4.04(0.43)$ & $3.99(0.44)$ & $4.10(0.45)$ \\
\hline $4,010-5,300$ (C) & $4.10(0.46)$ & $4.00(0.48)$ & $4.14(0.49)$ & $4.11(0.49)$ & $4.16(0.46)$ \\
\hline$\geq 5,310$ (D) & $4.16(0.50)$ & $4.07(0.53)$ & $4.20(0.53)$ & $4.17(0.53)$ & $4.23(0.53)$ \\
\hline$F$ & $15.050^{* * *}$ & $14.952^{* * *}$ & $13.789^{* * *}$ & $15.223^{* * *}$ & $9.151^{* * *}$ \\
\hline Scheffe post-hoc & $A<C, A, B<D$ & $A<C, A, B<D$ & $A<C, A, B<D$ & $A, B<C, A, B<D$ & $A<C, A, B<D$ \\
\hline \multicolumn{6}{|l|}{ Residence size } \\
\hline Metropolis (A) & $4.03(0.49)$ & $3.93(0.53)$ & $4.07(0.51)$ & $4.04(0.51)$ & $4.11(0.52)$ \\
\hline Rural (B) & $3.98(0.52)$ & $3.86(0.54)$ & $4.03(0.54)$ & $3.98(0.56)$ & $4.08(0.53)$ \\
\hline Mid-city (C) & $4.10(0.48)$ & $4.00(0.51)$ & $4.13(0.51)$ & $4.10(0.51)$ & $4.18(0.49)$ \\
\hline$F$ & $3.916^{*}$ & $3.982^{*}$ & $3.134^{*}$ & $3.453^{*}$ & $4.049 *$ \\
\hline LSD post-hoc & $A, B<C$ & $A, B<C$ & $A<C$ & $A<C$ & $A<C$ \\
\hline
\end{tabular}

Values are presented as mean (SD).

$\mathrm{CPLC}=$ Children's Pragmatic Language Checklist; $\mathrm{KRW}=$ Korean won; $\mathrm{LSD}=$ least significant difference

${ }^{*} p<.05,{ }^{* * * *} p<.001$. 


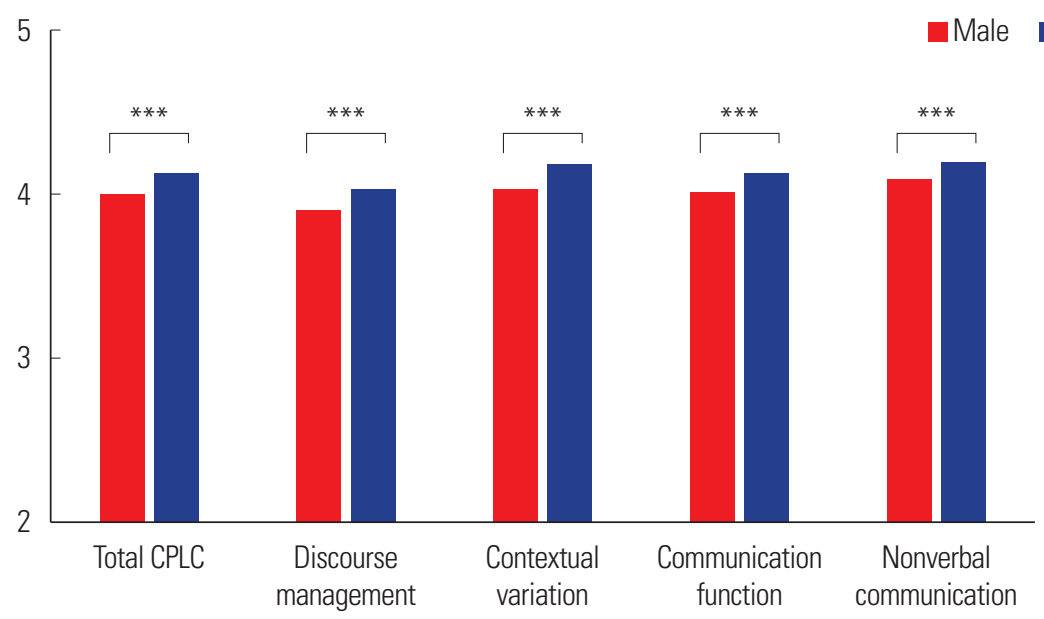

Figure 1. Comparisons of Children's Pragmatic Language Checklist (CPLC) mean between gender groups. ${ }^{* *} p<.001$.

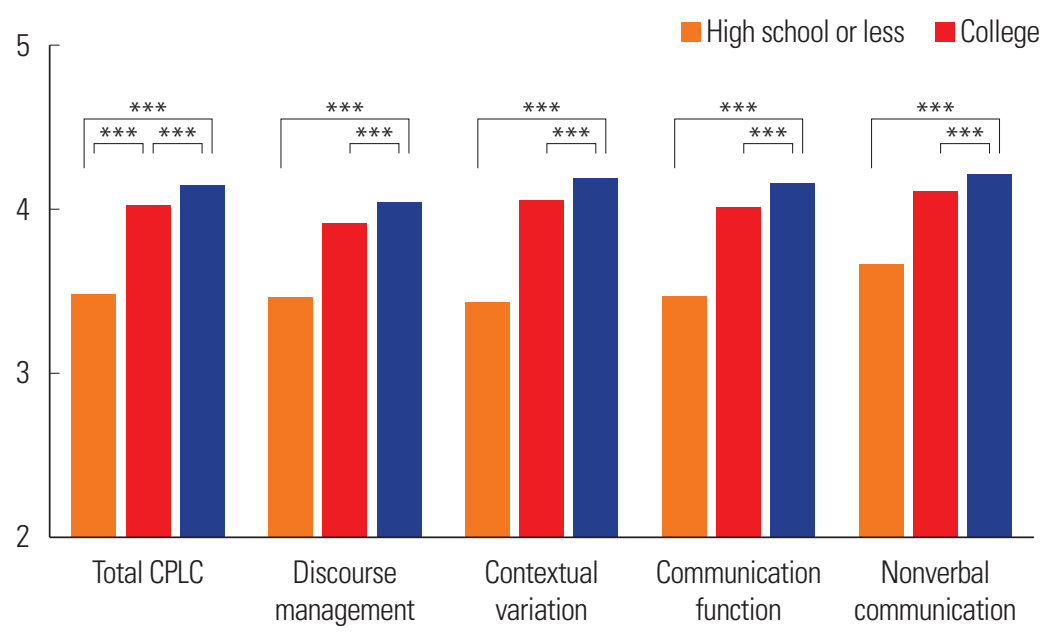

Figure 2. Comparisons of Children's Pragmatic Language Checklist (CPLC) mean among groups according to mother's education. ${ }^{* * *} p<.001$.

\section{어머니 취업 여부에 따른 아동화용언어능력}

어머니 취업 여부에 따라 아동의 화용언어능력을 살펴본 결과, 어머니의 취업에 따른 화용언어능력은 취업 집단이 총점 평균 4.08 , 미취업 집단이 총점 평균 4.06 으로 비슷하였으며, 나머지 하 위 영역 평균점수에서도 비슷한 수행을 보여, $t$-검정 결과 두 집단 간 유의한 차이를 보이지 않았다(Table 3).

\section{어머니 학력에 따른 화용언어능력}

어머니의 최종 학력에 따라 아동의 화용언어능력에 차이가 있는 지 살펴본 결과, 고졸 이하 학력 어머니를 둔 아동 집단이 전체 CPLC 평균 3.48 , 전문대졸 어머니를 둔 아동 집단이 4.01 , 대졸 이 상 학력의 어머니는 둔 아동 집단이 4.15 로, 전체 점수와 모든 하위 영역 점수에서 어머니 학력이 높아질수록 CPLC 평균점수도 높아
져 통계적으로 유의한 차이를 보였다(Table 3, Figure 2에 대한 설 명). 어머니 학력에 따른 화용언어능력의 Scheffe 사후검정 결과, 총 점과 상황에 따른 조절 영역에서는 세 집단 간 모두 유의한 차이가 있는 것으로 나타났고, 담화관리와 의사소통 기능 영역에서는 대졸 이상 학력 집단과 고졸 이하 집단 간 차이와 대졸 이상 집단과 전문 대졸 집단 간 차이가 유의하였다. 비언어적 의사소통 영역에서는 전 문대졸 집단과 대졸이상 집단 간에서만 유의한 차이가 나타났다.

\section{가정 소득수준에 따른 화용언어능력}

소득수준에 따른 아동의 화용언어능력에 차이가 있는지 알아보 기 위하여 일원분산분석을 실시한 결과 CPLC의 전체 평균과 하위 영역별 평균점수 모두에서 소득수준의 영향이 유의한 것으로 나타 났다(Table 3). 가정의 총소득이 340 만 원 이하 가정의 CPLC 평균 
은 3.91, 소득수준 341-400만 원 집단의 CPLC 평균은 4.00, 소득수 준 401-530만 원 집단의 CPLC 평균은 4.10, 소득수준 531만 원 이 상 가정의 CPLC 평균은 4.16 이었다. 가정 소득수준에 따른 화용언 어능력의 Scheffe 사후검정 결과, 의사소통 기능을 제외한 총점과 모든 하위 영역에서 소득수준 340만 원 이하 집단과 401-530만 원 집단 간, 소득수준 340 만 원 이하 집단과 531 만 원 이상 집단 간, 소 득수준 340-400만 원 집단과 531만 원 집단 간 차이가 유의한 것으 로 나타났고, 의사소통 기능 영역에서는 추가로 소득수준 340-400 만 원 집단과 401-530만 원 집단 간 차이도 유의한 것으로 나타났 다(Table 3, Figure 3에 대한 설명).

\section{거주지 규모에 따른 화용언어능력}

아동의 거주지 규모에 따른 화용언어능력을 살펴본 결과 대도시
거주 아동의 CPLC 평균은 4.03, 중소도시 거주 아동은 4.09, 읍/면 지역 거주 아동은 3.98 이었고 거주지 규모에 따른 아동의 화용언어 능력 차이가 유의한 것으로 나타났다(Table 3, Figure 4에 대한 설 명). 자세한 거주지 규모 간 차이를 살펴보기 위해 LSD 사후검정을 실시한 결과, CPLC 전체와 담화관리 영역에서는 대도시와 중소도 시 간, 중소도시와 읍/면 지역 간 차이가 유의했고, 상황에 따른 조 절, 의사소통 기능과 비언어적 의사소통 영역에서는 대도시와 중 소도시 간차이가 유의하게 나타났다.

\section{아동의 화용언어능력에 영향을 미치는 요인}

아동의 화용언어능력에 영향을 미치는 요인을 알아보기 위하여 아동의 성별과 가정의 소득, 어머니 학력(교육년수)을 독립변수로 아동의 CPLC 점수를 종속변수로 중다회귀분석을 실시하였다. 그

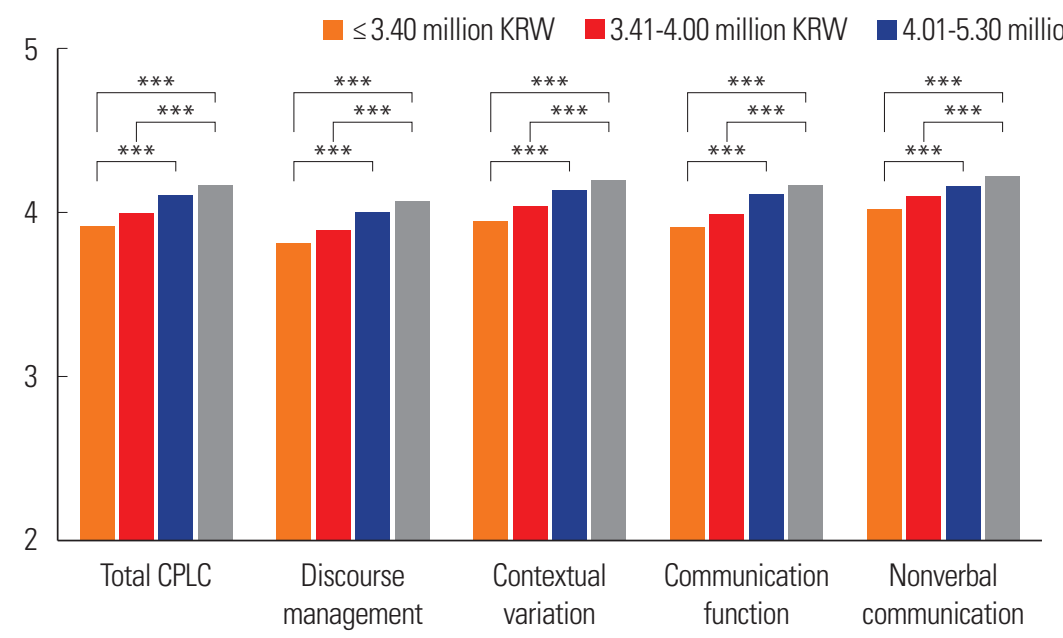

Figure 3. Comparisons of Children's Pragmatic Language Checklist (CPLC) mean among groups according to family income. ${ }^{* *} p<.001$.

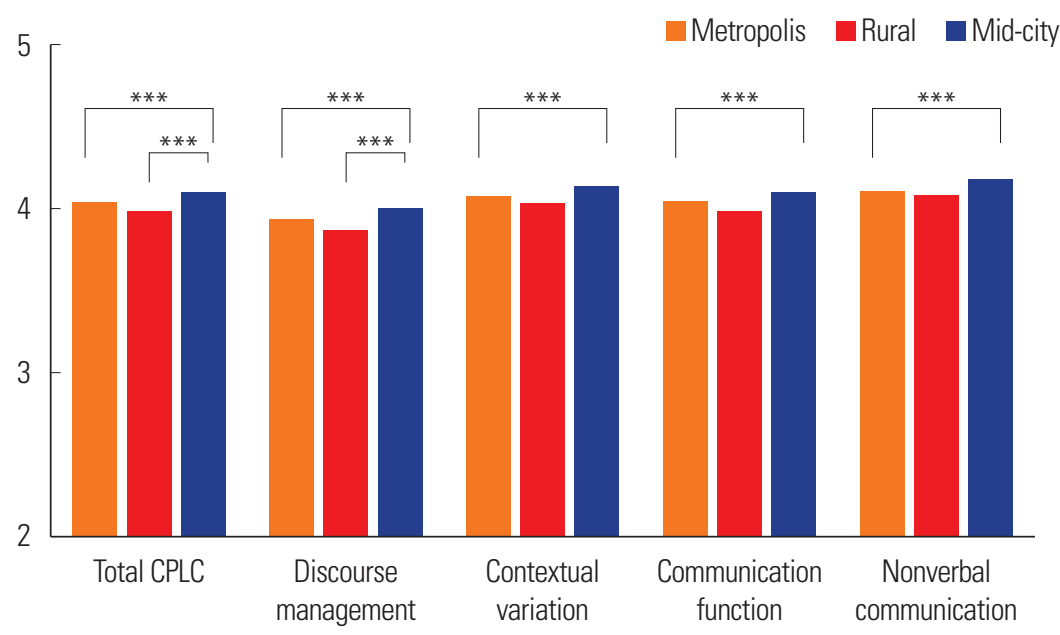

Figure 4. Comparisons of Children's Pragmatic Language Checklist (CPLC) mean among groups according to residence size. ${ }^{* * *} p<.001$. 
Table 4. Results of multiple regression analysis on CPLC by child and family related factors

\begin{tabular}{|c|c|c|c|c|}
\hline Dependent variable & Independent variable & $\beta$ & $\operatorname{Adj} R^{2}$ & $F$ \\
\hline \multirow[t]{2}{*}{ CPLC Total } & Mother education & .177 & .031 & $40.375^{* * *}$ \\
\hline & Mother Education+Child gender & $.178+.142$ & .050 & $33.809^{* * *}$ \\
\hline \multirow[t]{2}{*}{ CPLCDM } & Mother education & .161 & .025 & $33.142^{* * *}$ \\
\hline & Mother education+Child gender & $.162+.137$ & .043 & $29.114^{* * *}$ \\
\hline \multirow[t]{2}{*}{ CPLC CV } & Mother education & .182 & .033 & $42.836^{* * *}$ \\
\hline & Mother education+Child gender & $.183+.155$ & .056 & $37.739^{* * *}$ \\
\hline \multirow[t]{2}{*}{ CPLC CF } & Mother education & .178 & .031 & $40.631^{* * *}$ \\
\hline & Mother education+Child gender & $.179+.131$ & .047 & $31.806^{* * *}$ \\
\hline \multirow[t]{2}{*}{ CPLC NV } & Mother education & .138 & .018 & $23.954^{* * *}$ \\
\hline & Mother education+Child gender & $.138+.106$ & .029 & $19.263^{* * *}$ \\
\hline
\end{tabular}

$\mathrm{CPLC}=$ Children's Pragmatic Language Checklist; $\mathrm{DM}=$ discourse management; $\mathrm{CV}=$ contextual variation; $\mathrm{CF}=$ communication function; $\mathrm{NV}=$ nonverbal communication. ${ }^{* * *} p<.001$.

결과 CPLC 전체 평균에는 어머니 학력이 $3.1 \%(F=40.375, p<$ .001)의 설명력으로 긍정적인 영향을 미쳤으며, 어머니 학력과 아동 의 성별이 $5.0 \%(F=33.809, p<.001)$ 의 CPLC 총 평균을 설명하는 것으로 나타났다. 어머니 학력은 담화관리의 $2.5 \%(F=33.142$, $p<.001)$ 를 정적으로 설명하였으며, 어머니 학력과 아동의 성별은 담화관리의 $4.3 \%(F=29.114, p<.001)$ 를 설명하는 것으로 나타났다.

상황에 따른 조절 영역 점수에는 어머니 학력이 $3.3 \%(F=42.836$, $p<.001)$ 의 설명력으로 긍정적인 영향을 미치며, 어머니 학력과 아 동의 성별은 $5.6 \%(F=37.739, p<.001)$ 긍정적인 영향을 미치는 것 으로 나타났다. 어머니 학력은 의사소통 기능 점수의 $3.1 \%(F=40.631$, $p<.001)$ 를 긍정적으로 설명하며, 어머니 학력과 아동의 성별은 $4.7 \%(F=31.806, p<.001)$ 를 설명하는 것으로 나타났다. 비언어적 의사소통 점수에는 어머니 학력이 $1.8 \%(F=23.954, p<.001)$ 의 설 명력으로 긍정적인 영향을 미치며, 어머니 학력과 아동의 성별이 $2.9 \%(F=19.263, p<.001)$ 를 설명하는 것으로 나타났다(Table 4).

\section{논의 및 결론}

본 연구는 대규모 설문연구를 통해 전국 9 세 아동의 화용언어능 력이 영역별로 어떠한지 살펴보고, 아동 성별, 가정 소득, 어머니 학 력과 거주지 규모별 아동 화용언어능력 차이와 아동화용언어능력 에 영향을 주는 요인이 무엇인지 알아보는 데 목적이 있었다.

전체적으로 참여 아동들은 담화관리, 의사소통 기능 사용, 상황 에 따른 조절, 비언어적 의사소통 영역 및 전체적인 수행에서 양호 한 수준을 보였으며, 비언어적 의사소통이 가장 높은 평균점수를 보였고 담화관리에서 가장 낮았다. 같은 CPLC를 이용하여 학령기 아동의 화용언어능력을 알아본 선행연구(Oh et al., 2012)와 본 연 구의 9세 아동은 전반적으로 비슷한 수행을 보였다고 할 수 있다.
아동을 컴퓨터화된 시청각 과제로 직접 평가하는 방법으로 화용 언어능력을 연구한 Song, Kim, Lee와 Kim (2017)에서 3-4학년 아 동은 전반적인 화용언어 수행에서 저학년보다는 높고 고학년에 비 해서는 낮은 수행을 나타냈다. 그러나 본 연구에서와는 달리 가장 낮은 수행을 보인 영역은 CPLC의 상황에 따른 조절에 해당하는 의사소통 조율 영역이었다. 이러한 차이는 설문연구와 아동을 직 접 검사한 검사방법상의 차이에서 기인하는 것으로 판단된다. 또한 Song 등(2017)에서는 의사소통 조율을 애니메이션을 보고 공적/사 적 상황에 맞게 말 내용이나 목소리 크기, 존대표현의 적절성을 판 단하는 메타언어적, 메타화용적인 과제로 실시하였기 때문에 본 연구에서 어머니가 관찰한 아동의 상황과 상대방에 따른 조절 능 력과는 차이가 있었을 수 있다.

본 연구의 아동들이 담화관리 영역에서는 유일하게 평균 4점에 미치지 못한 것은 대화의 주제를 유지, 변경, 개시하고 의사소통 단 절을 해결하고 차례를 주고 받으면서 대화를 이끌어가는 능력은 초등 중학년 시기까지 가장 어려워하는 영역일 수 있음을 짐작케 한다. 구조화된 대화 자료를 이용하여 $1,3,5$ 학년 아동의 대화 화제 지표 발달을 살펴본 Park 등(2017)에서도 화제(주제)의 수와 유지 능력을 살펴본 결과 5 학년 아동은 1 학년이나 3 학년 아동에 비해 주 제당 대화차례 빈도수와 화제유지 비율이 높았으나 1학년과 3학년 사이에는 유의한 차이가 나타나지 않았다. 결론적으로 주제 관리 및 대화차례 주고받기 능력이 고학년에 유의미한 변화를 보일 수 있음을 시사한다. 이에 비해 상대방의 표정이나 눈빛, 제스처를 이 해하고 대화 시 적절한 거리를 유지하는 등의 비언어적 의사소통 영역은 제일 양호한 영역으로 나타나 9세 아동도 표정이나 몸짓, 눈 빛 등을 적절히 이해하고 표현할 수 있는 것으로 나타났다. 선행연 구에서 고기능 자폐범주성장애 아동이 구어외 수단으로 의사소통 의도를 표현하는 데 어려움이 있었던 데 비해(Jin \& Pae, 2014), 본 
연구의 9세 아동의 경우에는 이미 중학년 시기에도 표정이나 눈빛, 제스처 등을 이해하고 표현하는 데 문제가 없었음을 보여준다.

아동 화용언어능력의 집단 간 비교에서는 어머니 취업 여부를 제외한 아동 및 가정 환경 요인에 따른 차이가 대체로 유의한 것으 로 나타났고, 아동의 성별과 가정의 월평균 소득, 어머니의 최종 학 력과 거주지 규모에 따라 아동의 화용언어능력에 차이가 있었다.

성별에 따른 차이 분석 결과로는 여자 아동이 남자 아동에 비해 전반적 화용언어능력이나 세부 영역별 수행 수준이 높은 것으로 나 타났다. 전통적으로 남자 아동은 여자 아동에 비하여 어휘(Kim,

Kim, et al., 2018; Rice \& Hoffman, 2015)나 발음(Kim et al., 2017; Shriberg, Tomblin, \& McSweeny, 1999) 의사소통 능력(Ketelaars et al., 2009) 등 언어발달의 전 영역에서 다소 낮은 수행을 보이며, 의사 소통장애 출현율에서도 성비의 불균형이 보고되었다. 이러한 경향 성은 본 연구에서도 이어져 여자 아동들은 모든 영역에서 남자 아 동들에 비해 높은 수행을 보였고, 남자 아동이 3점대의 가장 낮은 점수를 보였던 담화 관리를 포함한 모든 영역에서 '그런 편이다'에 해당하는 4점 이상의 평균점수를 보였다. 그러나 학령기 포함 연령 에서 토큰 검사로 듣기 이해와작업기억력을 표준화한 Shin과 Kim (2010)에서는 유의한 성별 차이가 보고되지 않는 등 성별에 따른 영 향은 영역이나 연령에 따라 비일관적인 경향을 보이기도 하였다.

또, 어머니 학력이 높을수록 아동의 CPLC 전반적, 영역별 수행 이 우수한 것으로 나타났다. 어머니 학력은 가정의 사회경제적지위 를 대표하는 요인으로 대졸 이상의 학력 어머니를 둔 아동이 전문 대 졸업이나 고졸 이하 학력의 어머니를 둔 아동에 비해 대체로 우 수했으며 CPLC 전체 평균과 상황에 따른 조절에서는 세 학력 집단 간의 차이가 모두 유의하였다. 그러나 같은 아동 자료로 3세와 7세 에서의 어휘를 연구한 Kim, Song 등(2018)의 경우에는 어머니 학 력에 따른 차이가 유의하지 않았고, 말소리 오류율을 살펴본 Kim 등(2017)에서도 학력이 높아질수록 오류율이 낮아졌으나 그 차이 가 유의하지 않았다. 또한 본 패널연구에는 원래 장애 아동의 자료 도 일부 포함되어 있었는데 본 연구에서는 일반아동의 수행을 알 아보고자 이를 걸러내고 분석을 실시하였다. 장애 아동을 포함한 전체 패널 아동 자료에서는 같은 분류 기준으로 학력에 따른 집단 을 설정했는데도 불구하고 분석결과가 유의하지 않았다(Do et al., 2019). 어머니의 학력과 관련해 한 가지 흥미로운 것은 본 연구에서 유의한 변인인 어머니의 학력이나 가정 소득과 관련이 있어 보이는 어머니의 취업 여부는 아동의 수행에 유의한 차이를 가져오지 않 았다는 점이다. 이는 단순히 취업 여부보다는 어머니의 직업이 무엇 인가가 어머니 학력, 가정 소득과 직접적 관련이 있고 따라서 아동 의 화용 수행과 관련이 있을 가능성이 있음을 시사한다고 볼 수 있
다. 부모의 사회경제적지위와 아동의 어휘량 간의 관계를 연구한 Hart와 Resley (1995)의 경우에는 직업별로 전문직 부모를 둔 집단 과 노동자 계층 등으로 집단을 구분하였고, 그 결과 직업에 따른 유 의한 차이가 있었다. 아동의 화용언어능력에 영향을 주는 요인을 살펴보는 후속연구에서는 취업 여부보다는 부모의 직업을 변수로 설정하는 것이 바람직하다고 할 수 있다.

가정의 월평균 소득에 따라서도 아동의 전체적인 화용언어능력 이나 담화관리, 상황에 따른 조절, 의사소통 기능, 비언어적 의사소 통에서 유의한 차이가 나타났다. 해외나 국내 선행연구에서 가정 의 소득은 주로 저소득층과 중상위층의 두 집단 비교가 많았는데 본 연구에서는 가정의 소득을 총 4 개의 집단으로 세분화하여 살펴 보았음에도 소득이 많을수록 아동의 수행이 좋아지는 경향성이 유지되었다. 본 연구의 아동과 같은 아동이 참여한 $\mathrm{Kim}, \mathrm{Kim}$ 등 (2018)의 경우, 상위, 중위, 하위의 세 집단으로 나누어 살펴본 결과 집단 간 아동의 어휘능력 차이는 통계적으로 유의하지 않았다. 이 는 종속변수가 어휘능력과 화용언어능력으로 달랐던 이유일 수도 있고, 본 연구는 시작 전에 장애 아동 자료를 제외한 데 반해 Kim 등(2017)에서는 이러한 데이터 클리닝 작업을 실시하지 않았을 가 능성이 있을 수 있다. 실제로 장애 아동 자료까지 포함한 원래의 패 널 아동 자료에서는 소득수준의 영향이 유의하지 않은 것으로 나 타났다(Do et al., 2019). 다른 국내외 선행연구에서는 평균적인 소 득 집단과 저소득 집단의 두 개 집단으로 나눈 연구에서 친숙도와 투명도에 따른 관용어 이해에 차이를 보였으며, 저소득층 아동의 수행을 표준화검사 규준 자료와 비교한 연구들에서도 대체로 소 득에 따른 차이가 유의하였다(Han, 2011). 이에 비해 본 연구에서 는 소득에 따른 집단을 촘촘하게 구분했음에도 불구하고 집단 간 차이가 유의하였으므로 추후 화용언어 발달을 연구하거나 화용언 어능력을 평가, 중재할 때에 아동의 소득수준을 보다 세밀하게 고 려할 필요가 있다고 할 수 있다.

본 연구에서는 대도시나 읍/면 지역에 거주하는 아동보다는 중 소도시에 거주하는 아동의 화용언어능력이 높은 것으로 나타났 다. 이는 같은 아동의 7세 자료로 말소리 오류 및 말소리장애 출현 율을 연구한 Kim 등(2017)과는 다른 결과였다. Kim 등(2017)에서 는 읍/면 지역, 대도시, 중소도시 순으로 오류가 많은 것으로 나타 났으나 말소리장애 출현율은 오히려 중소도시에서 가장 높았고 집 단 간 차이는 유의하지 않았다. 규모가 큰 대도시에는 소득 분포가 다양한 사람들이 사는데 비해 읍/면 지역은 보통 농어촌 지역으로 경제적, 문화적으로 소외되어 있으며 상대적으로 낮은 SES를 보이 고 그에 따라 중소도시에 비해 낮은 수행을 보이는 결과를 가져왔 을 가능성이 있다. 
집단 간 차이 연구에서 유의한 변인이었던 어머니의 학력과 아동 의 성별은 중다회귀분석에서도 아동의 전반적인 화용언어능력 수 행이나 영역별 수행에 영향을 주는 요인으로 나타났다. 그러나 전 반적인 수행이나 영역별 수행에서 유의한 차이를 가져오는 요인이 었던 가정 소득은 영향을 주는 요인이 아닌 것으로 나타났다. 어머 니의 학력은 단독으로나아동의 성별 요인과 함께 CPLC의 총 평균 과 모든 하위 영역 평균에 영향을 주는 것으로 나타났으며, 설명하 는 비율은 대체로 $2 \%-5 \%$ 내외로 적은 편이었다.

이러한 연구결과를 종합해 볼 때, 학령기 중기 아동은 대화차례 나 주제를 유지하고 다양한 의사소통 기능을 이해, 표현하고 상황 과 상대방에 따라 자신의 말 특성을 변화시킬 수 있고, 표정이나 눈 빛, 제스처 또한 자연스럽게 의사소통에 사용할 수 있는 것으로 나 타났다. 아동의 화용언어 수행은 아동이 어느 지역에 거주하는가, 어머니의 학력과 가정의 소득, 성별에 따라 민감하게 달라졌으며, 그중에서도 어머니의 학력과 아동 성별은 화용언어능력의 일부를 유의하게 설명할 수 있는 요인으로 밝혀졌다.

본 연구는 지역별, 인구학적 균형을 갖춘 대규모 자료수집에서 나타난 9 세 아동의 화용언어 능력을 살펴보았다는 데 의의가 있다. 아동의 언어능력에 대한 어머니의 보고와 실제 관찰이나 진단 결 과와는 유의미한 상관이 있는 것으로 보고되고는 있지만 본 연구 결과를 아동의 평가와 중재에 적용할 때에는 실제 아동의 화용언 어능력을 관찰하거나 검사한 결과를 종합해 평가할 필요가 있다. 같은 연령대를 대상으로 아동의 화용언어능력을 비슷하게 다루고 있다고 하더라도 과제에 따라 다른 수행을 보일 수 있으므로 직접 관찰이나 어머니/선생님 보고에 의한 자료가 아닌 판단, 수정을 포 함하는 화용 과제의 경우 메타화용능력이 요구되어 더 어려울 수 있음을 알 수 있었다. 본 연구에서 유의미한 차이를 가져오는 요인 이었던 성별이나 어머니 학력, 가정 소득이나 거주지 규모는 선행연 구에서 같은 아동 자료를 이용했음에도 요인에 따른 집단의 수를 어떻게 설정하느냐에 따라 다르기도 하였고, 선행연구에서 두세 가 지 요인을 함께 분석하거나 종단적 자료를 비교한 경우에는 집단 간 차이 양상이 달라졌다. 그러므로 아동의 화용언어 능력을 평가 할 때에는 가정 환경을 고려해야 하지만 비교 집단 및 기준 설정을 면밀히 하여 분석할 필요가 있다. 대규모 연구를 통해 일반아동의 화용언어능력에 가정 환경 요인이 영향을 줄 수 있음을 확인하였 으므로 개인 차이가 더 광범위하고 다양한 양상을 보일 수 있는 장 애 아동의 경우에는 임상현장에서 이러한 요인을 더 세심히 고려 하여야 할 것이다.

앞으로는 종단 연구자료를 통해 본 연구결과의 경향성이 반복되 는지 지속적으로 살펴봄으로써 학령기 아동의 화용언어능력 발달
과 그에 영향을 주는 요인을 보다 명확히 할 필요가 있고, 선행연구 에서 화용언어능력과 관련이 있다고 보고된 학습능력이나 집행기 능, 정서행동 특성을 포함시켜 화용언어 수행을 살펴볼 필요가 있 다. 본 연구에서는 원래의 CPLC와는 달리 5점 척도를 사용하였는 데 앞으로 4점 척도를 사용한다면 기존의 CPLC의 민감도, 특이도 및 절단점 연구를 통해 화용 문제를 가진 아동의 비율 등도 살펴볼 수 있을 것이다.

\section{REFERENCES}

Arriaga, R. I., Fenson, L., Cronan, T., \& Pethick, S. J. (1998). Scores on the MacArthur Communicative Development Inventory of children from lowand middle-income families. Applied Psycholinguistics, 19(2), 209-223.

Bishop, D. V. (1998). Development of the Children's Communication Checklist (CCC): a method for assessing qualitative aspects of communicative impairment in children. The Journal of Child Psychology and Psychiatry and Allied Disciplines, 39(6), 879-891.

Bowey, J. A. (1995). Socioeconomic status differences in preschool phonological sensitivity and first-grade reading achievement. Journal of educational Psychology, 87(3), 476-487.

Brinton, B., \& Fujiki, M. (1984). Development of topic manipulation skills in discourse. Journal of Speech, Language, and Hearing Research, 27(3), 350358.

Brinton, B., Fujiki, M., \& Powell, J. M. (1997). The ability of children with language impairment to manipulate topic in a structured task. Language, Speech, and Hearing Services in Schools, 28(1), 3-11.

Broomfield, J., \& Dodd, B. (2004). Children with speech and language disability: caseload characteristics. International Journal of Language \& Communication Disorders, 39(3), 303-324.

Burchinal, M. R., Peisner-Feinberg, E., Pianta, R., \& Howes, C. (2002). Development of academic skills from preschool through second grade: family and classroom predictors of developmental trajectories. Journal of School Psychology, 40(5), 415-436.

Chiat, S., \& Polišenská, K. (2016). A framework for crosslinguistic nonword repetition tests: effects of bilingualism and socioeconomic status on children's performance. Journal of Speech, Language, and Hearing Research, 59(5), 1179-1189.

Corthals, P. (2010). Nine-to twelve-year olds' metalinguistic awareness of homonymy. International Journal of Language \& Communication Disorders, 45(1), 121-128. 
Craig, H. K., \& Evans, J. L. (1991). Turn exchange behaviors of children with normally developing language: the influence of gender. Journal of Speech, Language, and Hearing Research, 34(4), 866-878.

Davies, C., Andrés-Roqueta, C., \& Norbury, C. F. (2016). Referring expressions and structural language abilities in children with specific language impairment: a pragmatic tolerance account. Journal of Experimental Child Psychology, 144, 98-113.

Do, N., Lee, J., Kim, J., Jo, H., Park, E., \& Kim, H. (2019). The longitudinal study of growth and development on Korean children 2018 (panel study on Korean children II). Seoul: Korea Institute of Child Care \& Education.

Fernald, A., Marchman, V. A., \& Weisleder, A. (2013). SES differences in language processing skill and vocabulary are evident at 18 months. Developmental Science, 16(2), 234-248.

Fisher, E. L. (2017). A systematic review and meta-analysis of predictors of expressive-language outcomes among late talkers. Journal of Speech, Language, and Hearing Research, 60(10), 2935-2948.

Gleason, J. B., \& Ely, R. (2002). Gender differences in language development. In A. M. DeLish \& R. DeLisi (Eds.), Biology, society, and behavior: the development of sex differences in cognition (pp. 127-154). Westport, CT: Ablex Publishing.

Hammer, C. S., Morgan, P., Farkas, G., Hillemeier, M., Bitetti, D., \& Maczuga, S. (2017). Late talkers: a population-based study of risk factors and school readiness consequences. Journal of Speech, Language, and Hearing Research, 60(3), 607-626.

Han, N. Y. (2011). A comparative study on 4 and 5 year-old children's receptive, expressive language, vocabulary and word reading in terms of their families income levels: centrally a dense area of low-income group in G-si (Master's thesis). Kunkook University, Seoul, Korea.

Hart, B., \& Risley, T. R. (1995). Meaningful differences in the everyday experience of young American children. Baltimore, MD: Paul H. Brookes Publishing.

Hart, B., \& Risley, T. R. (1999). The social world of children: learning to talk. Baltimore, MD: Paul H. Brookes Publishing.

Heath, S. B. (1983). Ways with words: language, life and work in communities and classrooms. Cambridge, UK: Cambridge University Press.

Hoff, E. (2003). Causes and consequences of SES-related differences in parent-to-child speech. In M. H. Bornstein \& R. H. Bradley (Eds.), Socioeconomic status, parenting, and child development (pp. 147-160). Mahwah, NJ: Lawrence Erlbaum Associates.

Hoff, E. (2006). How social contexts support and shape language develop- ment. Developmental Review, 26(1), 55-88.

Hoff-Ginsberg, E. (1998). The relation of birth order and socioeconomic status to children's language experience and language development. Applied Psycholinguistics, 19(4), 603-629.

Huttenlocher, J., Vasilyeva, M., Waterfall, H. R., Vevea, J. L., \& Hedges, L. V. (2007). The varieties of speech to young children. Developmental Psychology, 43(5), 1062-1083.

Hwang, S. S. (2007). A study on language characteristics of children in culturally diverse family environments (Doctoral dissertation). Daegu University, Daegu, Korea.

Jin, Y. S., \& Pae, S. (2014). Communication profiles of school-aged children with social communication disorder and high-functioning autism. Communication Sciences \& Disorders, 19(1), 45-59.

Ketelaars, M. P., Cuperus, J. M., van Daal, J., Jansonius, K., \& Verhoeven, L. (2009). Screening for pragmatic language impairment: the potential of the children's communication checklist. Research in Developmental Disabilities, 30(5), 952-960.

Kim, H. K., Pae, S. Y., \& Yoon, H. J. (2013). Decoding and reading fluency for children from low-income families. Journal of Speech \& Hearing Disorders, 22(1), 55-68.

Kim, J., Kim, S. J., \& Do, N. H. (2018). Determining the relationship of children's socioeconomic background with vocabulary development: a longitudinal study of Korean children at 3 and 7 years of age. Communication Sciences \& Disorders, 23(2), 327-336.

Kim, M. R., \& Jung, K. H. (2017). Characteristics of idiom comprehension in school age children from low-income families. Communication Sciences \& Disorders, 22(2), 257-271.

Kim, S. J., Ko, Y. K., Seo, E. Y., \& Oh, G. A. (2017). Prevalence of speech sound disorders in 6-year-old children in Korea. Communication Sciences \& Disorders, 22(2), 309-317.

Kim, Y. T., Song, S. H., Kim, J. A., \& Kim, H. C. (2018). Validity and reliability of Korean meta-pragmatic language assessment for children. Communication Sciences \& Disorders, 23(1), 94-108.

Law, J., McBean, K., \& Rush, R. (2011). Communication skills in a population of primary school-aged children raised in an area of pronounced social disadvantage. International Journal of Language \& Communication Disorders, 46(6), 657-664.

Lee, M. S., \& Park, H. (2015). Children's communication and language learning abilities in community child care centers and child care center workers' perceptions of speech therapy services. Journal of Speech-Language 
\& Hearing Disorders, 24(3), 137-148.

Lee, Y., Heo, H., \& Jang, S. (2015). Standardization of the language scale for school-aged children (LSSC). Communication Sciences \& Disorders, 20(2), 290-303.

McDowell, K. D., Lonigan, C. J., \& Goldstein, H. (2007). Relations among socioeconomic status, age, and predictors of phonological awareness. Journal of Speech, Language \& Hearing Research, 50(4), 1079-1092.

Nippold, M. A. (2007). Later language development: school-age children, adolescents, and young adults (3rd ed.). Austin, TX: PRO-ED.

Oetting, J. B., \& McDonald, J. L. (2001). Nonmainstream dialect use and specific language impairment. Journal of Speech, Language, and Hearing Research, 44(1), 207-223.

Oh, S., Lee, E. J., \& Kim, Y. T. (2012). Preliminary study on developing test items of children's pragmatic language checklist. Journal of Speech \& Hearing Disorders, 21(2), 111-135.

Oh, S. J. (2018a). Validity study on Children's Pragmatic Language Checklist (CPLC). Journal of Speech-Language \& Hearing Disorders, 27(2), 125134.

Oh, S. J. (2018b). Correlation between Children's Pragmatic Language Checklist and conversation observations. Communication Sciences \& Disorders, 23(1), 109-118.

Park, Y. J., Choi, J., \& Lee, Y. (2017). Development of topic management skills in conversation of school-aged children. Communication Sciences \& Disorders, 22(1), 25-34.

Philofsky, A., Fidler, D. J., \& Hepburn, S. (2007). Pragmatic language profiles of school-age children with autism spectrum disorders and Williams syndrome. American Journal of Speech-Language Pathology, 16(4), 368-380.

Raghavan, R., Camarata, S., White, K., Barbaresi, W., Parish, S., \& Krahn, G. (2018). Population health in pediatric speech and language disorders: available data sources and a research agenda for the field. Journal of Speech, Language, and Hearing Research, 61(5), 1279-1291.

Rice, M. L., \& Hoffman, L. (2015). Predicting vocabulary growth in children with and without specific language impairment: a longitudinal study from 2 ;
6 to 21 years of age. Journal of Speech, Language, and Hearing Research, 58(2), 345-359.

Ripich, D. N., \& Griffith, P. L. (1988). Narrative abilities of children with learning disabilities and nondisabled children: story structure, cohesion, and propositions. Journal of Learning Disabilities, 21(3), 165-173.

Roseberry-McKibbin, C. (2007). Language disorders in children: a multicultural and case perspective. Boston, MA: Pearson/Allyn \& Bacon.

Sehley, S., \& Snow, C. (1992). The conversational skills of school-aged children. Social Development, 1(1), 18-35.

Shin, M., \& Kim, J. (2010). Standardization of the Korean Token Test for Children (KTC). Korean Journal of Communication Disorders, 15(2), 135-145.

Shriberg, L. D., Tomblin, J. B., \& McSweeny, J. L. (1999). Prevalence of speech delay in 6-year-old children and comorbidity with language impairment. Journal of Speech, Language, and Hearing Research, 42(6), 1461-1481.

Song, S., Kim, Y. T., Lee, S., \& Kim, J. A. (2017). Pragmatic language development and correlation with vocabulary ability of 4 -to 10-year-old typically developing Korean children using audio-visual discourse tasks. Communication Sciences \& Disorders, 22(2), 218-232.

Tough, J. (1977). The development of meaning: a study of children's use of language. New York, NY: Routledge.

Tough, J. (1982). Language, poverty, and disadvantages in school. In L. VernonFeagans \& D. C. Farran (Eds.), The language of children reared in poverty: implications for evaluation and intervention (pp. 3-18). New York, NY: Academic Press.

Walker, D., Greenwood, C., Hart, B., \& Carta, J. (1994). Prediction of school outcomes based on early language production and socioeconomic factors. Child Development, 65(2), 606-621.

Wilkinson, L. C., Wilkinson, A. C., Spinelli, F., \& Chiang, C. P. (1984). Metalinguistic knowledge of pragmatic rules in school-age children. Child Development, 55(6), 2130-2140.

Yoon, H. R., \& Kim, Y. T. (2004). Gender differences in language development of Korean infants. Communication Sciences \& Disorders, 9(1), 30-44. 


\section{국문초록}

\section{대규모 설문조사에 나타난 9세 아동의 화용언어능력: 성별과 사회경제적지위(SES)의 영향 오소정}

동명대학교 언어치료학과

배경 및 목적: 본 연구에서는 우리나라 9 세 아동의 화용언어능력을 부모가작성하는 아동화용언어체크리스트(CPLC)를 통해 알아보 고 아동 및 가정 환경의 요인에 따라 화용능력에 차이가 있는지 살펴보고자 한다. 방법: 한국육아정책연구소의 대규모 종단연구인 한 국아동패널 조사에 참여한 전국의 9 세 아동 1,386 명을 대상으로 부모보고 설문지인 CPLC를 작성하게 하였다. 전체 아동의 CPLC 총 점과 영역별 점수의 기술통계와 성별, 어머니 학력, 가정 소득수준, 거주지 규모별로 CPLC의 총점과 영역별 점수에 차이가 있는지 두 독립표본 $t$-검정과 일원분산분석을 실시하였다. 또 화용언어능력에 영향을 미치는 요인을 중다회귀분석을 이용하여 살펴보았다. 결과: 전반적으로 9세 아동은 CPLC의 총점과 담화관리, 상황에 따른 조절, 의사소통 의도, 비언어적 의사소통에서 양호한 수준을 나타냈으 며 가장 낮은 점수를 보인 영역은 담화 관리 영역이었다. 아동의 성별과 사회경제적지위(어머니의 학력과 가정의 소득수준)가 높을수 록 아동의 화용언어능력이 높은 것으로 나타났으며 화용언어능력에 영향을 주는 요인은 어머니의 학력과 아동의 성별이었다. 논의 및 결론: 본 연구는 성별과 SES 요인이 언어발달 후기에도 지속적으로 영향을 주며 언어의 의미나 형식뿐 아니라 의사소통 능력에도 영향 을 주고 있음을 보여주며, 학령기 아동의 의사소통 능력의 평가와 중재 시에도 이러한 요인을 고려하여야 함을 시사한다.

핵심어: 학령기 아동, 화용언어능력, 성별, SES, 아동화용언어체크리스트(CPLC), 한국아동패널연구

\section{참고문헌}

김미란, 정경희(2017). 학령기 저소득가정 아동의 관용어 이해 특성. Communication Sciences \& Disorders, 22(2), 257-271.

김수진, 고유경, 서은영, 오경아(2017). 우리나라 6세 아동의 말소리장애 출현율. Communication Sciences \& Disorders, 22(2), 309-317.

김영태, 송승하, 김정아, 김효창(2018). 한국아동 메타-화용언어검사(KOPLAC)의 개발: 타당도와 신뢰도 분석. Communication Sciences \& Disor-

ders, 23(1), 94-108.

김지순, 김수진, 도남희(2018). 아동의 사회경제적 배경과 어휘발달의 관계 탐색: 한국아동 3세, 7세 종단연구. Communication Sciences \& Disor-

ders, 23(2), 327-336.

김화경, 배소영, 윤효진(2013). 저소득층아동의 낱말해독 및 읽기 유창성. 언어치료연구, 22(1), 55-68.

도남희, 이정원, 김지현, 조혜주, 박은영, 김희수(2019). 한국아동 성장발달 종단연구 2018(한국아동패널연구II). 서울: 육아정책연구소.

박윤정, 최지은, 이윤경(2017). 초등학생 아동의 대화화제관리 능력의 발달. Communication Sciences \& Disorders, 22(1), 25-34.

송승하, 김영태, 이수정, 김정아(2017). 시청각적 담화 과제를 활용한 4-10세 아동의 화용언어 발달 및 어휘능력과의 상관도 연구. Communication

Sciences \& Disorders, 22(2), 218-232.

신문자, 김재옥(2010). 한국 아동용 토큰검사(Korean Token Test for Children)의 표준화 연구. 언어청각장애연구, 15(2), 135-145.

오소정(2018a). 아동화용언어체크리스트(CPLC)의 타당도 연구. 언어치료연구, 27(2), 125-134.

오소정(2018b). 아동화용언어체크리스트(CPLC)와 대화관찰 간 상관 연구. Communication Sciences \& Disorders, 23(1), 109-118.

오소정, 이은주, 김영태(2012). 화용능력 체크리스트 문항 개발을 위한 예비 연구. 언어치료연구, 21(2), 111-135.

윤혜련, 김영태(2004). 성별에 따른 영·유아 언어발달의 특성 연구: SELSI를 중심으로. 언어청각장애연구, 9(1), 30-44.

이명순, 박현(2015). 지역아동센터 아동들의 언어 및 학습 능력과 센터 종사자들의 언어치료 서비스에 대한 인식. 언어치료연구, 24(3), 137-148.

이윤경, 허현숙, 장승민(2015). 학령기 아동 언어 검사(LSSC) 표준화 연구. Communication Sciences \& Disorders, 20(2), 290-303.

진연선, 배소영(2014). 학령기 사회적의사소통장애와 고기능자폐 아동의 의사소통 능력 차이. Communication Sciences \& Disorders, 19(1), 45-59. 
한나영(2011). 저소득층 밀집지역에서 소득수준에 따른 만4, 5 세 유아의 수용-표현 언어발달, 어휘력, 단어읽기 비교: G시 저소득층 밀집지역을 중심 으로. 건국대학교 대학원 석사학위논문.

황상심(2007). 농촌지역 다문화가정 아동들의 언어 특성 연구. 대구대학교 대학원 박사학위논문.

\section{ORCID}

오소정(https://orcid.org/0000-0002-1427-5828) 